\title{
Świadkowie wiary... nieugięci, waleczni i święci
}

Ostatnie lata to czas obchodzenia rocznic tak ważnych dla historii Polski i historii Kościoła - 100. rocznicy odzyskania przez Polskę niepodległości, 100. rocznicy utworzenia w niepodległej Polsce Katolickiego Uniwersytetu Lubelskiego, czy 100. rocznica utworzenia Uniwersytetu Stefana Batorego w Wilnie, a przy nim wskrzeszenia Wydziału Teologicznego. Ale to także czas przygotowywania się do rocznic nie mniej ważnych dla dziejów Polski, jak 100-lecie rocznicy Bitwy Warszawskiej, czy 100-lecie urodzin św. Jana Pawła II.

Pamięć o minionych zdarzeniach mobilizuje i zachęca do tego, by nie zapomnieć także o tych, którzy o tę wolność walczyli z bronią $\mathrm{w}$ ręku, albo na kolanach, z wiarą i nadzieją w sercu, modlili się o dar wolności i niepodległości. Tych pierwszych często nazywamy bohaterami narodowymi. Są to osoby znane nam $\mathrm{z}$ kart podręczników do historii, zapisane $\mathrm{w}$ świadomości i pamięci narodowej Polaków, o których w minionych dniach mówiliśmy "Ojcowie Niepodległości": Józef Piłsudski, Roman Dmowski, Ignacy Jan Paderewski, Wincenty Witos, Wojciech Korfanty, czy Ignacy Daszyński. To są niewątpliwie najważniejsze osoby, które przyczyniły się do odbudowy państwowości po długich latach niewoli narodowej.

Ale wśród tych, których możemy nazwać „Ojcami Niepodległości” są również artyści, żołnierze i politycy, działacze społeczni, a także duchowni. Wielu z nich, urodzonych pod różnymi zaborami, reprezentujący rozmaite poglądy polityczne, różniący się przynależnością społeczną i zaangażowaniem politycznym, troszczący się jednak o wartość nadrzędną, jaką była wolna Polska. Potrafili się zjednoczyć wokół jednego, nadzwyczajnego celu, jakim była niepodległość Polski. Choć nie zawsze byli zgodni we wszystkim i we wszystkim wzorowo współpracowali, pozostając wierni własnym poglądom, to jednak wykorzystali sprzyjające warunki, by prowadzić Polaków do wolności.

Nie wolno nam zapomnieć o duchownych, którzy wpisali się w karty polskiej historii, jako ci, którzy o wolność zabiegali i o nią się starali. Wystarczy tu wspomnieć ks. Ignacego Skorupkę, kapelana Wojska Polskiego, który poległ 14 sierpnia 1920 roku pod Ossowem, stając się wręcz symbolem Bitwy Warszawskiej 1920 roku i gotowości oddania życia za wolną i niepodległą Ojczyznę.

A przecież duchownych - biskupów, kapłanów, zakonników, a nawet sióstr i braci zakonnych, którzy za niepodległość Polski gotowi byli oddać życie, pójść do łagrów i obozów koncentracyjnych, cierpieć prześladowania i szykanowania $\mathrm{i}$ to $\mathrm{w}$ różnych okresach historii Polski, było jakże wielu.

Prezentowana publikacja, wpisująca się $\mathrm{w}$ etos upamiętnienia tych, co za wolną Polskę walczyli, ginęli, gotowi byli cierpieć, ale i dla niej ciężko pracować, jest próbą przypomnienia tych duchownych, którzy na Ziemi Białostockiej dla 
dobra Rzeczypospolitej podjęli się żyć i pracować. A ponieważ troska o dobro wspólne, jakim jest niepodległa i wolna Polska, wyraża się nie tylko przez ofiarę z życia, czy walkę o wolność z bronią w ręku, ale przede wszystkim przez wierne trwanie i mozolne głoszenie prawdy o wolności.

A prawdziwą wolność mierzy się stopniem gotowości do służby i do daru z siebie - jak mawiał Jan Paweł II (homilia Jana Pawła II na zakończenie Międzynarodowego Kongresu Eucharystycznego, Wrocław, 1 czerwca 1997 r.) - Tylko tak pojęta wolność jest prawdziwie twórcza, buduje człowieczeństwo, buduje więzi międzyludzkie. Buduje i jednoczy, a nie dzieli!. „Ku wolności wyswobodził nas Chrystus!" (Ga 5,1).

Wyzwolenie z niewoli do wolności, tej politycznej, ale może jeszcze bardziej tej wewnętrznej, realizującej się w sercu i sumieniu jednostki, jest wielkim darem Boga dla całej społeczności, dla każdej jednostki. Staje się „darem i zadaniem", gdyż otrzymanie daru wolności zobowiązuje do troski o nią, dla dobra przyszłych pokoleń.

Przypominany Jan Paweł II zostawił po sobie ogromną spuściznę nauczania, w tym także dziedzictwo troski o pamięć o przeszłości naszej Ojczyzny. Wielokrotnie przytaczał słowa Pawła VI: „Człowiek naszych czasów chętniej słucha świadków aniżeli nauczycieli; a jeśli nauczycieli, to dlatego, że są świadkami”, zaznaczając, że autentyczna postawa zaangażowania także w życie społeczno-polityczne, zgodna z wyznawaną wiarą, jest najlepszym świadectwem także troski o wolność i niepodległość Ojczyzny.

Stąd pomysł na poniższą publikację. Nie tylko przypomnienie pięknych, ale $i$ trudnych kart $z$ historii naszej Ojczyzny, ale przede wszystkim ukazania na ich tle niezwykłych postaci zapisanych w dziejach Kościoła białostockiego.

Po II wojnie światowej, gdy przedwojenna Archidiecezja Wileńska została podzielona granicami państwowymi wyznaczonymi przez Wielką Trójkę w Teheranie, Jałcie i Poczdamie, w granicach nowo utworzonej Polski Ludowej znalazł się jej skrawek. Arcybiskup Romuald Jałbrzykowski, Metropolita Wileński, wyrzucony siłą przez sowietów z Wilna latem 1945 roku został zmuszony do organizacji życia kościelnego w nowych, powojennych, komunistycznych już czasach. Wszystko, co czynił, czynił z miłości do Boga i Kościoła, powierzonego mu Ludu Bożego. Ale tą miłością ogarniał także wszystko to, co polskie i narodowe. Także jego następcy na stolicy biskupiej w Białymstoku, choć nigdy nie zostali ordynariuszami diecezji, bo wciąż pełnili ,jedynie" funkcję administratorów apostolskich Archidiecezji Wileńskiej z siedzibą w Białymstoku: bp Władysław Suszyński i bp Adam Sawicki, oni także nie tylko kultywowali „tradycje wileńskie", ale świadectwem swego życia potwierdzali to, że służą Bogu i Ojczyźnie.

A pierwszy rektor powojennego białostockiego Seminarium Duchownego, ks. Ignacy Świrski, był nie tylko kapelanem w tracie wojny polsko-bolszewickiej w 1920 roku, ale także profesorem i dziekanem Wydziału Teologicznego Uniwersytetu Stefana Batorego. W trudnych dla Kościoła katolickiego w Polsce latach powojennych zapisał się w pamięci, jako „pasterz i ojciec”, wrażliwy 
na najuboższych i potrzebujących. Jego proces beatyfikacyjny rozpoczął się w 2017 roku.

Metropolita Białostocki, Edward Kisiel, był tym, który we własnej osobie łączył przez długie lata swego kapłaństwa to, co w Kościele białostockim było „wileńskie” - przedwojenne, z tym, co zostało utworzone, ukształtowane już w Białymstoku, na Ziemi Białostockiej. Wywodzący się z kresów diecezji wileńskiej, studia seminaryjne rozpoczął w Wilnie. Święcenia kapłańskie przyjął w okresie okupacji hitlerowskiej w Warszawie, ale całe swoje posługiwanie poświęcił Kościołowi białostockiemu, którego był pierwszym biskupem ordynariuszem i pierwszym arcybiskupem-metropolitą. Świadectwo swego świętego życia potwierdził niezwykłym wyznaniem na łożu śmierci: „Chorobę i śmierć przyjmuję z poddaniem się woli Bożej i ofiaruję w intencji kapłanów naszej archidiecezji - aby byli święci" (zakończenie testamentu abp. E. Kisiela, Białystok 1993).

Gotowość do ofiary i pracy dla dobra innych przejawiała się w różnorodnej formie zaangażowania duszpasterskiego. Księża pracowali ofiarnie w parafiach, we wspólnotach i ruchach, także dla dobra studiującej młodzieży tworząc w Białymstoku w czasach komunistycznych Duszpasterstwo Akademickie.

Ta troska o przyszłość przejawiała się także w codziennej pracy i posługiwaniu pasterskim abp. Edwarda Ozorowskiego, umiejętnie dzielącego czas między życie diecezjalne a zaangażowanie w naukę. Troska o polską rodzinę, o jej przyszłość opartą na chrześcijańskich i narodowych korzeniach stała się myślą przewodnią jego nauczania pasterskiego i teologicznego.

Jakże różnorodne i wielorakie było zaangażowanie pasterzy i duchownych Kościoła białostockiego w mozolną, codzienną pracę dla dobra Ojczyzny i Kościoła. Czerpali niewątpliwie wzór i przykład z nietuzinkowych pasterzy Kościoła powszechnego. Niewątpliwymi autorytetami byli: Papież Jan Paweł II i kard. Stefan Wyszyński, Prymas Polski. Nie tylko po kard. Wyszyńskim i św. Janie Pawle II pozostała ogromna spuścizna; dziedzictwo, do którego odwołują się kolejne pokolenia Polaków.

Pasterzy i duchownych Kościoła białostockiego też cechowała postawa niezłomna. Byli nieugięci w walce, o to, co święte i polskie, dla dobra powierzonej im pieczy wiernych. Nie ulękli się komunistycznego reżimu, ani spotykających ich szykan i prześladowań. Pozostali wierni Bogu i Kościołowi.

A przy tym - co najważniejsze - nie zapomnieli, by troszczyć się o świętość swego kapłańskiego życia! Przez co dali najpiękniejsze świadectwo. 